JSIP: Jurnal Studi Ilmu Pemerintahan

Volume 2, No 2 Agustus 2021

ISSN: 2722-7405

\title{
PERPECAHAN DAN SOLIDITAS ELITE PARTAI GOLKAR PADA PEMENANGAN PEMILIHAN WALIKOTA DAN WAKIL WALIKOTA TERNATE TAHUN 2015
}

\author{
Sofyan Muhamad
}

\begin{abstract}
Program Studi Ilmu Pemerintahan Universitas Pendidikan Muhammadiyah Sorong
\end{abstract} sofyanmip48@gmail.com

\begin{tabular}{l|l}
\hline Article Info & \\
\hline Keyword: & Abstract: Conflict and Division of political parties in Indonesia is not a new
\end{tabular}

Conflict, 1

Soliditas party ${ }^{2}$ Election $^{3}$

Kata Kunci:

Konflik ${ }^{1}$,

Soliditas Partai ${ }^{2}$,

Pemilihan Umum³ . issue. Still, the phenomenon had long been party Schism happened before, in the era of reform party politics have always been in a split case with hit never finished, one of the political parties are Golongan Karya, the ruling party during the new order Government has always been conflicts and the party's internal divisions, the year 2014 Golongan Karya again struck with the dynamics of the Division and gave birth to the dualism of the DPP at the level of stewardship, this research aims to look at the Division and solid elite DPD I Golongan Karya North Maluku on winning the election for mayor of the ternate year 2015. this research method used was qualitative case study method, in the technique of collecting data using interviews, documentation, and the withdrawal of conclusion; in this study, the theory used to analyze problems is an approach institutional political party, with this theory, the author can see solid and elite divisions Golongan Karya ternate city in the regional head election momentum the year 2015.

The results of the research some problems that occurred in the inner Golongan Karya ternate city, that the occurrence of structural conflict between Leader DPD I North Maluku with DPD II city of Ternate, in addition, there is also a policy dismissal several party cadres of the ternate town conducted by Chairman of DPD I North Maluku, the split of the party in the region are inseparable with the dynamics of the political elite at the central level, that the break at the level of DPP implicates against a decline of votes in the election of Golongan Karya regional heads of ternate city, the party defeats 2015 work on the caused level of the solid elite is not well-formed, and this dismissal policy is the starting point of the party elite and splits in the political interest of the element value in the selection of the head of the regional city of Ternate.

Abstrak: Konflik dan perpecahan parpol di Indonesia bukanlah isu baru. Namun fenomena tersebut sudah lama terjadi Skisma kepartaian, di era reformasi politik kepartaian selalu terbelah dengan pukulan tak kunjung usai, salah satunya adalah partai politik Golongan Karya, partai yang berkuasa pada masa orde baru Pemerintah selalu pernah terjadi konflik dan perpecahan internal partai, tahun 2014 Golongan Karya kembali diterpa dinamika perpecahan dan melahirkan dualisme DPP di tingkat kepengurusan, penelitian ini bertujuan untuk melihat Divisi dan elit yang solid DPD I Golongan Karya Maluku Utara dalam memenangkan pemilihan Wali Kota Ternate tahun 2015. Metode penelitian yang digunakan adalah metode studi kasus kualitatif, dalam teknik pengumpulan data menggunakan wawancara, dokumentasi, dan penarikan kesimpulan; dalam penelitian ini, teori yang digunakan untuk menganalisis permasalahan adalah pendekatan kelembagaan partai politik, dengan teori 
tersebut penulis dapat melihat solid dan elite divisi Golongan Karya Kota
Ternate dalam momentum pemilihan kepala daerah tahun 2015 .
Hasil penelitian beberapa permasalahan yang terjadi di Golongan Karya dalam
Kota Ternate, yaitu terjadinya konflik struktural antara Pimpinan DPD I Maluku
Utara dengan DPD II Kota Ternate, selain itu juga terdapat kebijakan pemecatan
beberapa kader partai Kota Ternate yang dilakukan oleh Ketua DPD I Maluku
Utara, perpecahan partai di daerah tidak terlepas dari dinamika elite politik di
tingkat pusat, sehingga pecahnya DPP di tingkat DPP berimplikasi pada
penurunan perolehan suara dalam pemilu. Kepala Daerah Golongan Karya Kota
Ternate, Partai Kekalahan 2015 Berkarya Disebabkan Tingkat Soliditas Elit
Tidak Terbentuk Dengan Baik, Dan Kebijakan Pemberhentian Ini Adalah Titik
Tolak Elit Partai Dan Terpecahnya Kepentingan Politik Unsur Nilai dalam
pemilihan kepala daerah Kota Ternate..

\section{PENGANTAR}

Perhelatan partai politik di era reformasi Golkar pada proses suksesi Pemilu Presiden 2014 secara internal tidak memilih/memutuskan calon Presiden dari partai yang berlambang pohon beringin ini, dinamika ini bagian dari titik awal terjadinya benturan atau berbeda pendapat sehingga mengara pada konflik sesama elite dalam tubuh partai Golkar di tinggakat pusat. Konflik elite Partai Golkar yang berjalan selama 1 tahun lebih terakhir tampaknya mulai kehilangan kepercayaan rakyat terhadap partai yang bersimbol pohon beringin ini. Bergulirnya era reformasi, suksesi kekuasaan politik Partai Golkar sebetulnya tidak selalu baik. Pada tahun 2014 Partai Golongan Karya (Golkar) di massa kepeminpinan Abruzal Bakri kembalih di guyur konflik di tingkat DPP, konflik ini berlangsung dalam agenda musawara nasional (Munas 2014).

Perpecahan elite di tingkat pusat merembet sampai ke tingkat DPD I Golkar Maluku Utara, dimana Partai Golkar kubu Aburizal Bakrie memecat sejumlah pengurus partai yang di kota ternate diantaranya Ikbal Rurai, Jumal Wange, dan Arifin Djafar selaku Ketua DPD II Golkar Kota Ternate, Jusman Arifin, Alwi Ishak, kebijakan atas pemecatan ini di sebabkan bahwa sebagian kader partai golkar kota ternate melangkahi intruksi atas keputusan DPD I Golkar mauku utara dan membagun konsulidasi untuk memberikan dukungan kepada kubu Agung Laksono, maka partai golkar dalam suksesi pemilihan kepala daerah secara serentak pada tanggal 9 desember 2015 mendatang di warnai dengan perpecahan elite di tingkat daerah, maka dalam penelitian ini yang akan di teliti adalah melihat dinamikan perpecahan dan soliditas elite partai golkar kota ternate dalam pemenangan pemilihan walikota dan wakil walikota ternate periode 2015-2020, di samping itu penulis akan menulusuri faktor-faktor apa sajah yang melatarbelakangi sehingga partai golkar kota ternate berada pada ruang lingkup perpecahan elite dan bagaimana partai golkar kota ternate menjaga soliditas elite partai dalam momentum pilkada kota ternate tahun 2015.

\section{METODE PENELITIAN}

Dalam artikel ini jenis penelitian menggunakan pendekatan metode studi kasus'(case studies) kualitatif, ada beberapa definisi mengenai pendekatan studi kasus (case studies) menurut Suharsimi (2002:120) adalah penelitian yang dilakukan secara intensif, teliti, dan mendalam terhadap suatu organisasi, lembaga, atau gejala tertentu.

\section{HASIL DAN DISKUSI \\ Perpecahan Elite Partai Golkar Kota Ternate}

Pertikaian dalam internal partai politik skhusunya di Indonesia selalu saja mengara pada dinamika perpecahan para elite, dinamika semacam ini sering kali di lihat dari cara elite partai politik menafasirkan platform dan kebijakan internal atas isu-isu tertentu ini sangat berpengaru dalam membentuk pragmatisme elite politik yang akan berpotensi merusak soliditas partai politik. Kekuasaan sering kali dijadikan sebagai tujuan utama elite partai politik, walaupun tujuan dari partai politik adalah merebut dan mempertahankan kekuasaan, di namika ini membuat para elite parpol dan politisi kemudian memanupilasi orientasi utama perjuangan parpol yang seharusnya iyalah berkontribusi dalam membagun tatanan masyarakat yang ideal berdasarkan platform atau ideology yang dianut, dalam pergeseran orentasi ini dengan 
sendirinya mengurangi peran ideology dalam membangun militansi dan soliditas partai politik. Berikut hasil wawancara dengan Abdulgani Sangaji Ketua DPD II Golkar Kota Ternate:

"Jadi yang pertama itu perpecahan di tingkat DPP, bahwa khusus kita di Maluku utara golkar tetap solid menghadapi pilkada seretnak 2015, karena semua DPD kab/kota adalah produk hasil munas pekanbaru 2009". ( wawancara tanggal, 15 Februari 2018).

Perpecahan yang terjadi dalam tubu partai golkar bermulah di tingkat DPP dan melahirkan dua kubu yaitu kubu Abrizal Bakire dan Agung Laksono, dan golkar Maluku utara menggap bahwa dinamika ini hanya akan terjadi di tingkat pusat tidak berpengaru ketingat provinsi maupun kab/kota yang ada di Indonesia, perpecahan internal partai golkar memakan waktu hampir 1,5 tahun selama perseturan ini terus berlangsung partai golkar menjadi tren topic yang selalu saja di wajanakan baik dari kalangan politisi maupun kalangan akademisi di tanah air, banyak yang beranggapakan dinamika perpecahan yang melimpah parati golkar adalah bagian dari proses kedewasaan para elite partai untuk jelih sehingga daalam proses menyelesaian harus benar-benar berada pada koridor organisasi partai.

"Menurut fredyy Matalata mengingatkan bahwa putusan selah PTUN terdiri dari dua hal yang pertama adalah menundah keabsahan surat hasil munas ancol dan tidak bisa diberlakukan dan kedua ialah kubu angung laksono tidak dibolekan membuat keputusan-keputusan atas nama partai golkar" red.(Freddy Latumahina tanggal 24 Januari 2015).

Dalam pernyataan ini yang disampikan oleh korwil Maluku dan Maluku utara adalah bagian dari sebua iktiar politik, tetapi secara tidak langsun perpecahan di tingkat DPP berpengerahu ketinggat daerah sehingga perselisihan elite di tingkkat lokal pun menuai kontrak atas perpecahan di tinggat pusat, berbagai macam maneuver politik yang di lakukan oleh elite politik partai golkar yang ada di kota ternate membuat situasi internal khusunya di Maluku utara makin memanas sehingga melahirkan faksi yang mengatasnaman mereka adalah bagian dari pengurus pro Anggung Laksono.

"Freddy Latumahina juga mengemukakan hasil rapat pleno tentang pemberhentian ketua DPD II Kota Ternate Arifin Djafar, Arifin Djafar diberhentikan karena terbuki berhiyanat dan menyebrang ke kubu Angung Laksono dan masih ada sejumlah kader Golkar yang berali dukungan ke kubu Agung Laksono di nataranya Jusman Arifin, Hamid usman, Ikbal Rurai, Jumal Wange, Alwi Ishak, dan Muhlis Tamanyira". ungkap (Freddy Latumahina tanggal 24 Januari 2015).

Pentingannya konsulidasi demokrasi di jadikan sebagai dasar, arah dan tujuan partai politik semua itu sangat jelas di tuangkan dalam UU No 2 tahun 211 tentang partai politik, dalam pasal 10 UU Partai politik menjelaskan bahwa orientasi partai politik ialah memajukan kehidupan demokrasi berdasarkan pancasilah serta menjaga mudaya dan etika politik di tanah air, hal ini diperkuat dalam pasal 27 dan 28 AD/ART partai golkar menyatakan bahwa dalam pengambilan keputusan pada hakikatnya dilakukan secara demokratis dan sesuai dengan ketentuan-ketentuan yang suda di atur dalam aturan organisasi partai.

Tabel 1. Pemecatan Kader Partai Golkar di Kota Ternate Tahun 2015

\begin{tabular}{|r|l|c|c|}
\hline No. & \multicolumn{1}{|c|}{ Nama } & Jabatan & Status Keanggotaan \\
\hline 1 & Arifin Djafar & Ketua DPD II Kota Ternate & Di Pecat \\
\hline 2 & Ikbal Rurai & Ketua Harian Golkar Maluku Utara & Di Pecat \\
\hline 3 & Jusman Arifin & Anggota DPRD Provinsi Maluku Utara & Di Pecat \\
\hline 4 & Jumal Wange & Badan Penasehat Golkar Kota Ternate & Di Pecat \\
\hline 5 & Samsir Andili & Anggota DPD II Golkar Kota Ternate & Di Pecat \\
\hline 6 & Alwi Ishak & Anggota DPD II Golkar Kota Ternate & Di Pecat \\
\hline 7 & Muhlis Tamanyira &
\end{tabular}

Sumber: Wawancara denga Sekertais DPD I Golkar Maluku Utara, Tanggal 19 februari 2018

Lemahnya memahami ideologi dan menguatnya pragmatisme ini menjadi alasan terjadinya perpecahan partai politik di era reformasi. Sebagai contoh selama era reformasi, terdapat sejumlah masalah internal partai terjadi akibat perpecahan dukungan calon dalam pemilu, terutama pemilihan presiden (pilpres). Hal ini seperti pernah terjadi di internal Partai Golkar pada Pilpres 2014, perpecahan terjadi akibat anggota partai seringkali mendukung calon presiden/wakil presiden berbeda dengan apa yang ditetapkan partai politik. Hal ini karena dalam memilih capres potensial, baik anggota dan partai, tidak lagi melihat atas dasar kesamaan 
ideologi, visi dan misi mereka namun lebih pada potensi kemenangan dari sisi popularitas dan sumber daya finansial. Dengan demikian, setiap faksi di dalam partai dapat saja memandang berbeda tentang siapa yang layak dicalonkan di dalam pemilu.

\section{Skema Konflik dan Perpecahan Elite Partai Golkar}

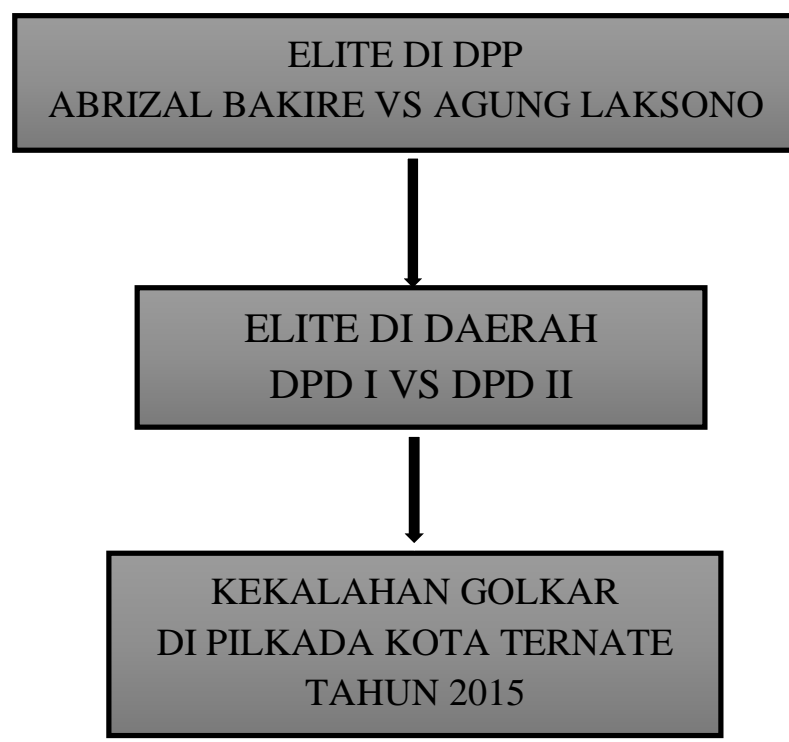

\section{Soliditas Elite Partai Golkar Kota Ternate}

Pasca jatunya presiden Soeharto, terdapat banyak fenomena menarik dalam partai politik salah satunya adalah kegagalan menjaga soliditasnya, sejarah partai golkar era reformasi selalau sejah di perhadapkan dengan fenomena perpecahan sehingga terdapat beberapa partai politik yang sekaran ini lagi eksis adalah bagian dari pecahan partai yang berlambang pohon beringin, hal semacam ini menandakan bahwa partai golkar tidak mampu menjaga soliditas elite partai, walapun usia partai golkar sudu cukup lamah tetapi dalam melembagakan internal partai masih jauh dari harapan, golkar selalu sajah menjadi isu yang sangat menaraik dalam kajian perpcahan partai politik di tanah air. Sejumlah kalangan beraggapan bahwa kegagalan partai golkar untuk menjaga soliditas di karenakan internal tidak mengedepankan azaz otonom dalam penyelesain perselisian yang terjadi dalam tubuh partai, interfensi pihak eksternal memiliki ruang yang cukup terbuka untuk turut terlibat dalam perpecahan ini, hal semacam ini yang akan membuat partai golkar kehilangan arah untuk menjadi solusi dalam hal penyelesain perselisihan antara elite partai, di dalam partai golkar terdapat satu wada yaitu Mahkama partai, wada ini adalah tempat untuk untuk menyelesaikan belbagai pokok persoalan, tetapi mahkama partai di anggap bukan solusi yang terbaik untuk menyelesaikan polemic dalam tubuh partai golkar, fonomena semacan ini yang akan melemahkan partai golkar untuk menjaga soliditas, berikut ini wawancara dengan salah satu kader partai yang di pecat.

"Kebijakan Ketua DPD I atas pemecatan ini bagi saya dan teman-teman adalah sebuah keputusan yang keliru, memang keliru polemik di DPP kita Maluku utara main pecat, seharunya kebijakan dari ketua DPD I menkonsulidasikan agar kita pengurus di Malut tetap solid, bukan main pecat sajah" (wawancara pada tanggal 10 februari 2018).

Dari pemaparan di atas kita melihat bahwa, kebijakan yang dilakukan oleh DPD I yang mengatasnaman pendukung ARB sangat tidak demokratis, kebijakan ini tanpa mempertimbangkan dalam proses pengambilan keputusan, di dalam AD/ART partai golkar menjeleskan bahwa dalam pengambilan keputusan harus melalui forum-forum musawara atau rapat-rapat pleno, sehingga keputusan yang di hasilkan tidak merugikan pihak lain dan harus bersifat demokratis, setiap partai politik memiliki aturan partai sebagai pijakan untuk menyelesaikan pokok permasalahan dalam internal partai, maka polemik yang terjadi dalam partai golkar harus jadikan AD/ART sebagai pedoman penyelesaikan masalah.

Partai Golkar Maluku utara di perhadapkan dengan dinamika perpecahan antara elite menjelang pilkada serentak yang akan diselenggarakan pada tahun 2015, perpecahan ini tidak terlepas dari dinamika politik elite di tingkat pusat yang melahirkan kubuh Abrijal Bakrie dan Agung Laksono atau dalam istilah munas bali vs munas ancol, dinamika perpecahan ini 
berlangsung 1,5 tahun menjelang pilkada 2015, akibat dari perpecahan ini golkar Maluku utara kehilangan keseimbangan untuk menjaga soliditas elite dalam menghadapi pilkada serentak khususnya di kota ternate, kekalahan partai golkar dalam pemilihan walikota dan wakil walikota ternate adalah sebuah kenyataan yang harus diterima oleh partai golkar, kebijakan ketua DPD atas pemecatan sejumlah kader golkar kota ternate membuat soliditas elite telah mencair dalam pilkada serentak, kebijakan ini terkesan adalah salah satu faktor utama kekalahan partai golkar dalam pemilihan walikota dan wakil walikota ternate tahun 2015.

Pernyataan yang di sampaikan oleh ketua tim koalisi bahwa, kader partai golkar dalam suksesi pemilihan walikota dan wakil walikota ternate tingkat soliditas secara internal partai tidak terbagun dengan baik, fenomena perpecahan ini bermulah ketia ketua DPD II kota ternate Arifin Djafar di pecat dan di gantikan oleh Hidayat Djafar Sah sebagai plt, menuai pro dan kontrak di kalangan elite partai yang ada di kota ternate, fenomena ini telah memperlihatkan alite yang mendukung kebijakan ini da nada pulah yang menolak kebijakan atas pemecatan arifin djafar sebagai ketua DPD II kota ternate, hal semacan ini yang berpengaru terhadap soliditas elite dalam momentum pilkada 2015 khusunya di kota ternate.

\section{Perpecahan Partai Golkar Dalam Pemilihan Walikota dan Wakil Walikota Ternate Tahun 2015}

Tahun 2015 adalah tahun politik yang berlangsung pada bulan Desember mendatang, seluruh partai politik di tanah air turut meramaikan kontestasi dalam hajatan pesta demokrasi, partai politik berloba-lomba melakukan penjaringan dalam pengusungan bakal calon kepala daerah, kerasnya persaingan dalam pencalonan ini membuat tak sedikit partai politik terpecah dan tidak berada dalam satu komando, Partai Golkar di tenga-tenga perhelatan pilkada serentak 2015, partai yang berlambang pohon bering ini kembalih diguyur konflik dan perpecahan elite di tinggat pusat sampai berakhir dengan dulisme kepengurusan, dinamika ini yang pastinya membuat kegaduhan pengurus di tinggat daerah sebab hajatan politik 2015 adalah hajatan pemilihan kepalah daerah, maka sudah pastinya pengurus di tingkat daerah memiliki andil yang cukup besar.

" Ketika Ketua DPD Kota Ternate bapak Arifin Djafar di pecat dan gantikan dengan bapak Hihayat Djafar menui pro dan kontrak dalam internal partai golkar kota ternate, disinilah awal terjadinya perpecahan dalam tubuh partai golkar kota ternate" (wawancara pada tanggal 8 Maret 2018).

Dalam peryataan yang di sampaikan oleh ketua harian partai golkar Maluku utara, ada titik terang bahwa kebijakan yang dilakukan oleh DPD I atas pemecataan ketua DPD II kota ternate menuai pro dan kontrak sehingga kebijakan ini melahirkan konflik dan perpecahan elite yang ada di daerah, pentingnya konsulidasi internal yang masif dalam momentum pilkada serentak, konsuidasi struktur dapat di pahami dalam bentuk penguatan kepengurusan partai baik di tingkat provinsi dan kab/kota, bentuk konflik dan perpecahan bisah dapat diselesaikan lewat forum-forum musyawara secara internal partai, maka perlu partai politik melakukan konsulidasi secara internal dan eksternal demi menjaga soliditas elite, Arifin Djafar selaku ketua DPD II kota ternate dan menjabat sebagai wakil walikota ternate harus menerimah kebijakan atas pemecatan dirinya, pemecatan ini menjadi pembahasan yang cukup hangat dalam internal partai golkar kota ternate, ada yang beranggapan bahwa kebijakan DPD I maluku utara atas pemecatan ketua DPD II kota ternate telah melanggar aturan main dalam tubuh partai golkar, pada hal sosok arifin djafar adalah sosok figure yang akan di usung dalam kontestasi pilkada di kota ternate, ketika pemecatan ini berlangsung partai golkar yang mengatas namakan pendukung abrijal bakrie memberi dukungan ke partai gerindra dalam kontestasi pemilihan walikota dan wakil walikota ternate dengan mengusung Sujud Siradjudin sebagai calon walikota ternate dan posisi arifin djafar yang bukan lagi kader partai telah mendampingi sujud siradjudin dalam momentum ini.

Pemilihan walikota dan wakil walikota ternate dalam data KPU terdapat empat pasangan calon, tiga pasangan calon di usung oleh partai politik dan satu lewat jalur independen, untuk meihat kekuatan politik di parlemen kota ternate pasangan Burhan Abdullraham dan Abdullah taher memiliki modal politik yang cukup besar ketimbang rival politik yang lain, partai golkar kota ternate berada pada posisi partai pendukung sebab ketika Arifin Djafar di pecat golkar kekurangan kader yang potensial untuk di usung sebagai calon walikota ternate tahun 2015, Arifin Djafar yang waktu itu masih menjabat sebagai wakil walikota aktif berada pada posisi urutan perta maka bakal calon yang memiliki elektabilitas yang baik. 
“ Kebijakan DPD I atas pemecatan ini membuat keretakan dalam tubuh partai golkar kota ternate, pada hal bapak arifin djafar sosok figure yang baik, putra daerah dan satu-satunya perwakilan kesultanan dan kebijakan DPP lebih memilih calon non kader ini lebih menui pro dan kontrak kalau suda terjadi pro dan kontrak maka mesin politik yang bekerja tidak maksimal". (wawancara pada tanggal 10 Februari 2018).

\section{Kekalahan Partai Golkar Pada Pemilihan Walikota Ternate}

Pemilihan kepalah daerah yang di laksanakan pada tanggal 9 Desember mendatang, membuat partai politik harus melakukan konsulidasi struktural sampai di tingkat desa secara massif, persaingan politik dalam momentum pilkada adalah sebuah persaingan yang cukup ketat di mana partai politik secara internal akan mempersiapkan belbagai strategi untuk keluar sebagai partai pemenang dalam pilkada serentak di tahun 2015, Maluku utara yang terdiri dari $10 \mathrm{Kab} /$ Kota, delapan di antaranya di ikutsertakan dalam pemilihan bupati dan wakil bupati/walikota dan wakil walikota, partai politik dalam momentum pilkada memiliki peran atas kesuksesan demokrasi di tanah air karena partai politik adalah bagian dari pilar demokrasi, harapan publik yang pastinya menginginkan proses demokrasi berjalan dengan aman dan damai dan tidak melahirkan kegaduhan dan perpecahan di kalangan masyarakat.

Tabel 2. Calon Walikota dan Wakil Walikota Ternate \& Koalisi Partai Politik Tahun 2015

\begin{tabular}{|c|l|c|c|}
\hline No. & \multicolumn{1}{|c|}{ Pasangan Calon } & Partai Koalisi & Jumlah Kursi \\
\hline $\mathbf{1}$ & Sujud Siradjudin \& Arifin Djafar & Golkar, Gerindra, PAN & 9 Kursi \\
\hline $\mathbf{2}$ & $\begin{array}{l}\text { Sidik Dero Siokona \& Jasman } \\
\text { Abubakar }\end{array}$ & PDIP, Nasdem, PKS & 9 Kursi \\
\hline $\mathbf{3}$ & $\begin{array}{l}\text { Burhan Abdurahman \& Abdullah } \\
\text { Tahir }\end{array}$ & $\begin{array}{l}\text { PKB, PBB, PPP, Hanura, } \\
\text { PKPI, Demokrat }\end{array}$ & 14 Kursi \\
\hline $\mathbf{4}$ & Rachman Sulaiman \& Anwar & Independen & - \\
\hline
\end{tabular}

Sumber: KPU Kota Ternate

Pilkada serentak tahun 2015 khusunya kota ternate terdapat empat pasangan calon walikota dan wakil walikota ternate, partai golkar kota ternate berkoalisi dengan partai gerindra dan PAN, untuk mengusung pasangan No urut satu yaitu Sujud Siradjudin dan Arifin Djafar sebagai calon walikota dan wakil walikota ternate periode 2015-2020 dengan jumah kursi di DPRD sembilan kursi maka dengan modal politik partai koalisi belum bisah mengimbangi posisi petahan dengan perolehan 14 kursi DPRD.

Partai Koalisi pasangan nomor urut satu (SUJUD-AJA) mengharapkan partai-partai tetap solid, bentuk iktiar politik ini kemudian datang dari partai gerindra sebagai partai pengusung, perpecahan partai golkar di tahun 2014 dan melahirkan dualisme cukup di sayangkan jika konflik ini tidak diselesaikan secara cepat, mengingat bahwa 2015 adalah momentum pilkada serentak, jangan sampai partai yang berlambang pohon beringin mengalami kekalahan atau penurunan suara di pilkada serentak, momentum pemilihan presiden 2014 masih menyisakan satu bentuk fenomena di mana konflik dan perpecahan terjadi dalam partai politik, partai golkar ketika menjelang pemilihan presiden dan paska pemilihan presiden golkar di guyur konflik dan perpecahan, terdapat sejumlah akademisi/pengamat politik melihat bahwa perpecahan ini harus cepat-cepat diselesaikan sebab 2015 adalah pemilihan kepalah daerah maka partai-partai politik yang mengalami perselisihan pendapat harus segera di satukan kembalih demi menjaga soliditas internal, sama hal dengan pandangan yang disampaikn oleh sala satu akademisi universitas muhammadiyah Maluku utara Agus Mawanda, dalam pandangannya adalah partai golkar harus melakukan islah di antara dua kubu jika dua kubu tidak melakukan konsulidasi untuk islah maka partai yang berlambang pohon bering ini akan kehilang basis pemilih di momentum 2015.

Tabel 2. Calon Walikota dan Wakil Walikota Ternate \& Koalisi Partai Politik Tahun 2015

\begin{tabular}{|c|l|c|c|c|}
\hline No. & \multicolumn{1}{|c|}{ Pasangan Calon } & Partai Koalisi & Perolehan Suara & Persentase \\
\hline 1 & $\begin{array}{l}\text { Sujud Siradjudin \& Arifin } \\
\text { Djafar }\end{array}$ & Golkar, Gerindra, PAN & 21.369 Suara & $24,77 \%$ \\
\hline 2 & $\begin{array}{l}\text { Sidik Dero Siokona \& } \\
\text { Jasman Abubakar }\end{array}$ & PDIP, Nasdem, PKS & 34.015 Suara & $39,42 \%$ \\
\hline
\end{tabular}




\begin{tabular}{|c|lr|c|c|c|}
\hline 3 & $\begin{array}{l}\text { Burhan Abdurahman \& } \\
\text { Abdullah Tahir }\end{array}$ & $\begin{array}{l}\text { PKB, PBB, PPP, Hanura, } \\
\text { PKPI, Demokrat }\end{array}$ & 29.115 Suara & $33,74 \%$ \\
\hline 4 & $\begin{array}{l}\text { Rachman Sulaiman \& } \\
\text { Anwar }\end{array}$ & Independen & 1.788 Suara & $2,07 \%$ \\
\hline
\end{tabular}

Sumber: KPU Kota Ternate

Hasil pemilihan walikota dan wakil walikota ternate periode 2015-2020, dapat dilhat bahwa posisi petahan keluar sebagai pemenang, dan pasangan calon yang usung oleh partai golkar berada pada posisi ketiga dan PDIP menempatkan posisi pemenang kedua dalam pemilihan walikota dan wakil walikota ternate di tahun 2015, berikut ini wawancara dengan ketua bapillu partai golkar kota ternate Asgar Asagaf:

"kekalahan kami di pemilihan walikota karena Plt ketua DPD II kota ternate tidak mampu mengkonsulidasikan kembali mesin politik agar tetap solid, masalah perpecahan dan konflik bagi saya suda selesai maka elite partai khusunya di ternate harus lebih mengfokuskan dalam kontestasi ini, bukan karena arifin djafar suda bukan lagi kader partai lalu kita tidak bekerja secara maksimal". (wawancara pada tanggal 17 maret 2018).

Dalam pernyataan di atas menjelaskan bahwa partai golkar kota ternate, pasca di guyur konflik dan perpecahan antara elite berimbas pada soliditas partai sehingga suksesi pilkada serentak 2015 jauh dari harapan, sejarah politik partai golkar kota ternate, partai golkar selalu keluar sebagai pemenang dalam pemilihan walikota ternate, konflik dan perpecahan elite partai golkar kota ternate denandakan bahwah partai yang berlambang pohon beringin ini tidak memeliki kemampuan dalam mengelola dinamika perbedaan yang terjadi antara elite partai, situasi semacam ini bisah membahayakan bagi bangsa dan Negara sebab partai politik bisa sajah menjadi penabur benih konflik, konflik dalam partai politik selalu sajah mengara pada dinamika perpecahan elite dan terjadi faksi dalam internal, hal semacam partai politik khusunya golkar akan kehilangan basis pemilih daerah tertentu, sebab publik akan merasa gaduk atas dinamika ini dan bisa saja pemilh akan berpidah ke partai lain.

Pasagan calon walikota dan wakil walikota ternate yang di usung oleh tiga partai politik yakni, partai golkar, partai gerindra dan PAN keluar sebagai pemenang ketiga, dari tujuh kecamatan terdapat hanya satu kecamatan yang di menangkan oleh pasangan Sujud Siradjudin dan Arifin Djafar, di kecamatan Mot Dari hasil rekapitulasi suara di tujuh kecamatan posisi petahan meraup suara terbanyak dan keluar sebagai pemenang dalam pemilihan walikota dan wakil walikota ternate periode 2015-2020, berikut ini wawancara dengan ketua bappilu partai golkar kota ternate Asgar Asagaf:

"partai gokar kota ternate, memiliki modal politik yang cukup bagus, kita kemarin dalam pileg 2014 kota ternate kita keluar sebagai partai pemenang suarah terbanyak, dari modal politik ini kami yakin akan memenangkan pilwako di tahun 2015, semua itu jau dari harapan, saya melihat bahwa kekalahan dalam pilwako di sebabkan tidak ada soliditas yang terbagun dengan baik antara elite partai" (wawancara pada tangga 17 maret 2018).

Dalam momentum pilkada serentak di kota ternate, partai yang berlambang pohon bering ini telah menorekan sejarah pahit akibat partai penguasa di kota ternate ini dapat di tumbangkan oleh partai-partai politik yang lain, kekalahan dalam pilkada kota ternate menjadih catatan penting untuk partai golkar, di mana partai golkar dalam sejara berpolitikan di kota ternate khusunya dalam pemilihan walikota dan wakil walikota tidak terkalan dan mereka selalu sukses mengantarkan pasangan calon yang mereka usung, berikut ini wawancara dengan ketua bappilu partai golkar kota ternate Asgar Asagaf:

"kami kalah dalam pilwako ternate karena kader partai tidak solid,sebab ada yang kurang suka dengan sosok arifin djafar dan ada yang pro terhadap arifin djafar, perpecahan ini bermuah ketika waktu itu pak arifn djafar di pecat sebagai ketua DPD II kota ternate, kebijakan ini ada kelompok yang menilai cacat hukum dan menolak atas keputusan ini di lain pihak mendukung ada yang mendukung atas keputusan ini". (wawancara pada tangga 17 maret 2018).

Kebijakan ketua DPD I Ahmad hidayat mus atas pemecatan ketua DPD II kota ternate berimlikasi pada keretakan dalam internal partai golkar kota ternate, pemecatan ini menuai pro dan kontrak di mana sebagian kader memposisikan diri untuk melakukan pemebelaan terhadap Arifin Djafar agar posisi sebagai ketua DPD II kota ternate di pertahankan, fonomena percahan partai golkar adalah bagian dari konflik structural antara ketua DPD I Ahmad hidayat mus dan 
Arifin Djafar selaku ketua DPD II kota ternate, konflik ini ada kaitannya dengan polemik yang terjadi di tingkat pusat, sebab pemecatan ketua DPD II kota ternate di nilai bahwa arifin djafar melakukan konsulidasi di sepiluh kab/kota yang ada di Maluku utara untuk mendukung munas ancol atau versi Agung Laksono.

\section{KESIMPULAN}

Berdasarkan pada hasil penelitian yang telah diuraikan dalam Pembahasan di atas dapat di uraikan bahwa perpecahan dan soliditas elite partai golkar pada pemenangan walikota dan wakil walikota ternate Tahun 2015, mulai dari tahapan pilkada serentak di kota ternate, partai golkar selalu diwarnai oleh beberapa fenomena internal antara alite partai di mana terjadih perselisihan antara sktuktur partai DPD I Maluku utara dan DPD II kota ternate dan berakhir pada pemecatan sejumlah kader golkar kota ternate sehingga soliditas elite partai telah mencair dan harus menerimah kekalahan dalam pemilihan walikota dan wakil walikota ternate periode 2015-2020, Maka untuk menganalisis perpecahan dan soliditas elite partai golkar kota ternate pada pemenangan pemilihan walikota dan wakil walikota ternate tahun 2015 maka akan diuraikian sebagai berikut:

1. Perpecahan partai golkar berawal dari dinamika perpecahan elite di tingkat pusat, dalam Munas tahun 2014 melahirkan dualisme kepengurusan yaitu Abrizal Bakrie dan Agung Laksono dan berimbas di DPD I Maluku utara, DPD I golkar Maluku utara memecat sejumlah kader partai golkar kota ternate yang di anggap mendukung kubu Agung Laksono

2. Pemecatan terhadap ketua DPD II kota ternate Arifin Djafar dan di gantikan Hidayat Djafar Sjah sebagai plt menuai pro dan kontrak antara elite, di mana ada yang sepakat dengan keputusan DPD I dan yang monolak keras atas keputusan ini

3. Ketua DPD I Ahmad Hidayat Mus dalam kebijakan ini di nilai tidak demokratis dan tidak mengara pada pelanggaran secara substantive, dan terkesan sepihak dan merugikan kader yang ada kota ternate

4. Pemecatan Ketua DPD II kota ternate dan beberapa pengurus partai yang lain karena di anggap melakukan konsullidasi di tingkat kab/kota untuk memberikan dukungan ke kubu munas ancol, fenomena ini adalah bagian dari titik awal terjadinya perpecahan elite partai golkar di daerah menjelang pilkada serentak tahun 2015

5. Kekalahan partai golkar dalam pemilihan walikota ternate 2015 di karenakan tingkat soliditas elite telah mencair dan tidak terbentuk dengan baik, akibat dari perpecahan antara elite partai yang mengakibatkan partai golkar dengan pasangan calon yang di usung harus menerimah kekalahan dalam pemilihan walikota dan wakil walikota ternate tahun 2015

6. Kebijakan ketua DPD atas pemecatan sejumlah kader partai terdapat unsur kepentingan politik baik jangka panjang maupun jangka pendek, kebijakan ini dinilai bahwa ketua DPD I Maluku utara mau membagun dinasti politik dalam internal partai golkar Maluku utara

7. Soliditas elite partai golkar Maluku utara tidak terbangun dengan baik, di mana polemik yang terjadi di tingkat DPP golkar Maluku utara saling memecat antara kader partai, fenomena ini yang mengakibatkan konflik dan perpecahan elite menjelang pilwako ternate tahun 2015.

\section{REFERENSI}

Arsyad, A. \& Kambo, G. 2013 Konflik ketiga elit pada pemilihan Walikota \& Wakil Walikota Makasar 2013.

Astriya, D. (2014). Konflik Internal Partai Amanat Nasional (PAN) di Provinsi Lampung Tahun 2013 (Studi Kasus Pemberhentian Ketua Dewan Pimpinan Wilayah (DPW) PAN

A Padallingan, M. (2012). kekalahan Partai Golkar Pada Pemilukada Di kabupaten Toraja Utara 2010 (Doctoral dissertation). 
Asmadianto, A., \& Nurmandi, A. (2016). Konflik Internal Dan Rekrutmen Politik Partai Golkar Sulawesi Barat Menghadapi Pemilu dan Pilkada di Sulawesi Barat 2014). Journal of Governance and Public Policy.

Andriadi, Fayakhun, 2014. Golkar Transformer RMBOOKS Graha Pena, Jakarta.

Asep, Nurjana, 2013. Ketidak stabilan Electoral Dan Kehancuran Politik Aliran UMM Press, Malang.

Budiarjo. 2008. Dasar-Dasar Ilmu Politik PT Gramedia Pustaka Utama Jakarta.

Bogdan, Robert C and Biklen. 1982 Qualitative Reasearch for Education an Introduction To Theori and Methods Boston Alin And Bacon.

Efriza, 2012. Political Explore, Sebua Kajian Ilmu Politik, Cv Alfabeta, Bandung

Effendi, A. T. (2015). Dampak Konflik DPP Partai Golkar Terhadap DPD Partai Golkar Kota Surabaya (Doctoral dissertation Universitas Erlangga).

Eristyawan, F. N. (2013). Pelembagaan Partai Kebangkitan Bangsa (Studi Kasus Kemerosotan Suara pada Pemilihan Umum Tahun 2009 di Jawa Timur)

Noor, Firman. 2015. Quo Vadis Demokrasi Kita "PT Wahana Semesta Intermedia Jakarta.

Noor, Firman. 2015. Perpecahan Dan Soliditas Partai Islam di Indonesia LIPI Press Jakarta.

Firmanzah, 2011. Mengelola Partai Politik, Komunikasi Dan Positioning Ideologi Politik Di Era Demokrai Yayasan Pustaka Obor Indonesia, Jakarta.

Faisol, A. 2014. Konflik internal PDI-Perjuangan Tahun 2005-2009

Kaunar, A. (2011). Pusaran Politik Dalam Rekrutmen Kandidat Partai Golkar (Studi Tentang Rekrutmen Kandidat Oleh Partai Golongan Karya Pada Pemilihan Walikota dan Wakil Walikota Ternate Periode 2010-2015) (Doctoral dissertation, Universitas Gadjah Mada).

Huntington, P. Samuel 2004. Tertib Politi, Pada Masyarakat Yang sedang Beruba PT Raja Grafindo Persada Jakarta.

Halid, Nurdin. 2016. Suara Golkar Suara Rakyat Jetpress Jakarta.

Halim Abdullah, 2014. Politik Lokal, Pola, Aktor \& Alur Dramatikanya LP2B Yogyakarta.

Imansyah, T. (2012). Regulasi partai politik dalam mewujudkan penguatan peran dan fungsi kelembagaan partai politik. Jurnal Rechts Vinding Media Pembinaan Hukum Nasional.

Irtanto. 2008. Dinamika Politik Lokal Era Otonomi Daerah Pustaka Pelajar, Yogyakarta.

Joko, J. Prihatmoko Moesafa. 2008 Menangkan Pemilu Di Tengah Oligarki Partai Pusta Pelajar Yogyakarta.

Jainuri. 2010. Pergumulan Politik, Antara Elit Partai Di Aras Lokal UPT Universitas Muhammadiyah Malang Press Malang.

Labolo Dan Tegu 2017. Partai Politik Dan Sistem Pemilu Di Indonesia, Teori, Konsep Dan Isu Strategis Rajawali Pres Jakarta.

Lofland, John dan Lin H. Lofland. 1984 Analizing Social Setting a Guide To Qualitative Observation And Analizing Belmont Compani (Terjemahan).

Thoha, Miftah. 2014. Birokrasi Dan Dinamika Kekuasaan Prenadamedia Group Jakarta.

Misrina, M. (2015). Metamorfosis Faksionalisme Internal Partai Golkar di Maluku Utara pada PILKADA 2007. Jurnal Studi Pemerintahan: Journal of Government and Politics.

Marijan, 2010. Sistem Politik Indonesia, Konsulidasi Demokrasi Pasca-Orde Baru Kencana Prenada Media Group Jakarta.

Muliansyah. 2015. Political Ilmu Politik Demokrasi Partai Politik Dan Welfare State Buku Lentera Yogyakarta.

Moleong. 2001. Motede Penelitian Kualitatif Remaja Rosda Karya, Bandung.

Mufti. 2013. studi Organisasi Politik Moderen Cv Pustaka Setia Bandung.

Mukhtar. 2013. Metode Praktis Penelitian Deskriptif Kualitatif Jakarta Referensi.

Nazir, Moh. 2009. Metode Penelitian Ghalia Indonesia. Bogor.

Pamungkas, Sigit. 2009 Perihal Pemilu Labolatorium Jurusan Ilmu Pemerintahan \& Jurusan Ilmu Pemerintahan Fisipol UGM Yogyakarta.

Pamungkas, Sigit. 2011. Partai Politik, Teori Dan Praktik Di Indonesia Perum Griya Saka Permai Yogyakarta. 
Qodir, Zuly. 2016. Teori Dan Praktek Di Indonesia Memahami Partai Pemilu Dan Kejahatan Politik Pasca-Orde Baru Pustaka Pelajar Yogyakarta.

Romli, L. (2016). Masalah Kelembagaan Partai Politik di Indonesia Pasca-Orde Baru. Jurnal Penelitian Politik.

Randall dan Svasand.2002. Party Institutionalization in New Democracies Party Politics.

Surbakti, Ramlan. 2010. Memahami Ilmu Politik PT Gramedia Widiasarana Indonesia Jakarta.

Suharsimi, Arikuntoin. (2002). Prosedur Penelitian Suatu Pendekatan Praktek PT Rineka Cipta Jakarta.

Subekti. 2014. Partai Syarikat Islam Indonesia Kontestasi Politik Hingga Konflik Kekuasaan Elit Yayasan Pustaka Obor Indonesia Jakarta.

Sugiyono. 2011. Metode Penelitian Kuantitatif Kualitatif dan R \& D. Alfabeta

Bandung.

Umar, Ibnu Alkhatab. 2009. Dari Beringin Ke Beringin Sejarah Kemelut Resistensi Dan Daya Tahan Partai Golkar Ombak Yogyakarta.

Warachma, T. (2014). Konflik Internal Partai Golkar Pada Pemilihan Walikota Makasar 2013 (Doctoral dissertation) 